\title{
PAVEMENT SUBGRADE STABILIZATION WITH LIME AND CELLULAR CONFINEMENT SYSTEM
}

\author{
Muhammet Vefa AKPINAR ${ }^{1 \star}$, Erhan Burak PANCAR ${ }^{2}$, Eren ŞENGÜL ${ }^{3}$, Hakan ASLAN ${ }^{4}$ \\ ${ }^{1}$ Karadeniz Technical University, Civil Engineering Dept, Trabzon, Turkey \\ ${ }^{2}$ Samsun Ondokuzmayis University, Architectural Dept, Samsun, Turkey \\ ${ }^{3}$ Devlet Su Isleri Trabzon Bolge Mudurlugu, Turkey \\ ${ }^{4}$ Sakarya University, Civil Engineering Dept, Sakarya, Turkey
}

Received 10 January 2017; accepted 17 March 2018

\begin{abstract}
In this study effectiveness of lime stabilization and geocell reinforcement techniques of roads was investigated for low bearing capacity subgrades. For this purpose, a large-scale plate load test was designed and used. Clayey soil with high moisture content was reinforced with different percentages of hydrated lime $(5 \%, 10 \%, 15 \%$ dry weight of the soil). The deflection and stress results indicated that lime stabilization or geocell reinforcement alone did not significantly increase subgrade reaction coefficient and bearing capacity values. Promising results were obtained on stabilization of weak subgrade when both techniques were used together. It was determined that cellular reinforcement increased the reaction modulus coefficient value and bearing capacity of the subgrade soil by more than $15 \%$ compared to the lime stabilization.
\end{abstract}

Keywords: bearing capacity, geocell reinforcement, high water content, lime stabilization, pavement, subgrade.

\section{Introduction}

Lime stabilization has gained more acceptance compared to any other techniques applied to pavement layers especially on weak subgrade soils to increase the bearing capacity. Lime added to the soil allows for an increase in deformation resistance of the soil by increasing shear strength and resilient module of the soil.

Kavak (1996) reviewed unconfined compression resistances of pure bentonite and kaolin clays by stabilizing them with lime. As a result of their experiments, unconfined compression resistance of the clay showed 6 times increase in 1 month. They stated that resistance increases had continued in the long-term. Figure la shows the results of unconfined compression strength of cured samples of various time intervals by mixing lime to kaolin clay. Figure $1 \mathrm{~b}$ shows unconfined compression strengths of bentonite clay cured with lime.

Sivapullaiah, Kantha, and Kirian (2003) reviewed the behavior of Terra Rosa soil by adding $20 \%$ bentonite, $1 \%$ cement and $1 \%$ lime. The samples prepared for various additive rates were subjected to consolidation and unconfined compression experiments after 0,7 and 28 days of cure. They concluded that cement-bentonite mixture in- creased the shear strength fast within 7 days, while bentonite-lime mixture increased the resistance after 7 days.

In their studies, Kavak, Güngör, Avşar, Atbaş, and Akyarlı (2008) reviewed the behaviour of lime stabilization on Ankara-Bala- Kulu highway that was 14 meters wide. The pavement subgrade layer was stabilized with $1 \%, 2 \%$, $3 \%, 4 \%$ and $5 \%$ lime in two layers. The lime amount was determined as $5 \%$ of dry soil weight. It was observed that while dry CBR values of the material to which $5 \%$ lime was mixed at the end of 56 days increased 8 times, up to 34 times increases occurred on its wet CBR values compare to the natural material (Figure 2). Plate loading experiments showed that the largest deformation decreased from $22.18 \mathrm{~mm}$ to $3.58 \mathrm{~mm}$ (Figure 3). When coefficient values of reaction modulus were reviewed, lime-stabilized base layer had 6 times higher $\mathrm{K}$ value compared to the state without lime.

Yıldırım, Alataş, and Dağdelen (2009) conducted experiments on soil-asphalt mixtures. Their experiment on unconfined compression tests showed that largest unconfined compression resistance was obtained at $3 \%$ asphalt content. CBR values given by that study were two times higher than natural soil when mixed with asphalt that resulted in 5.2\% cost saving in pavement layer design thickness.

*Corresponding author. E-mail: mvakpinar@ktu.edu.tr 

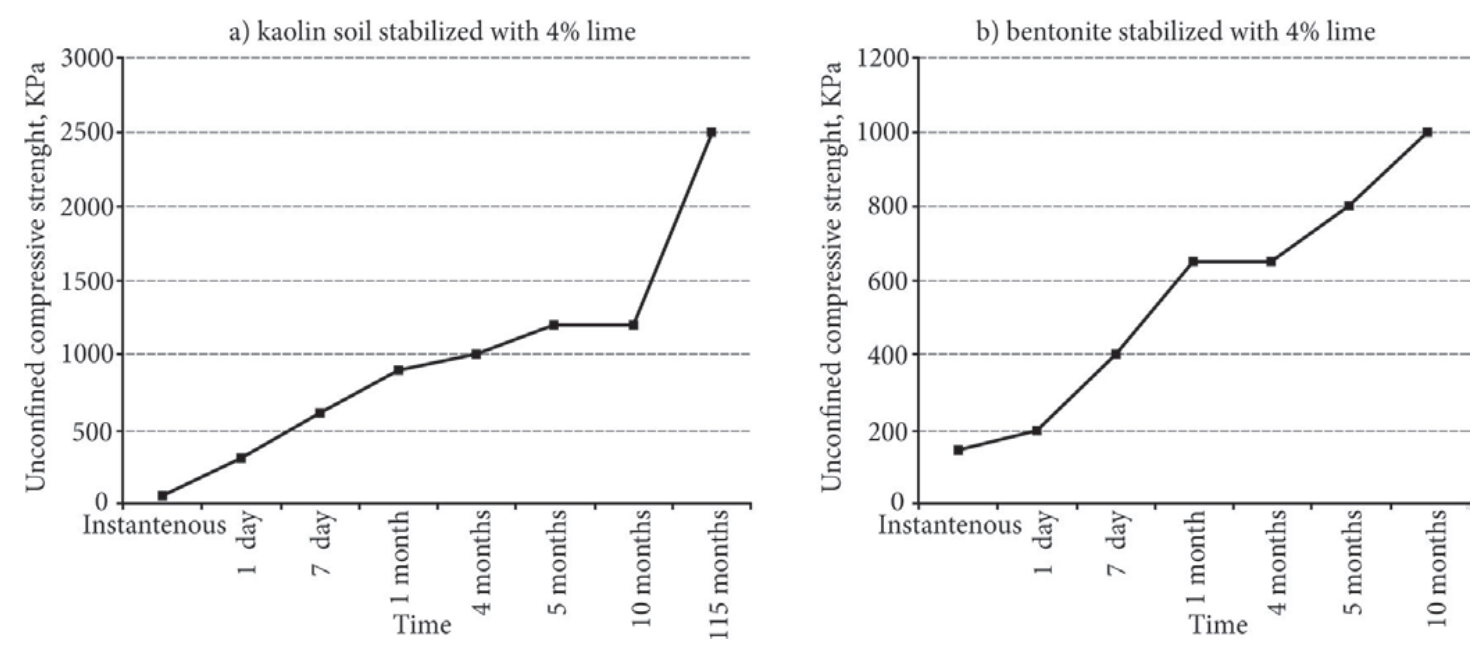

Figure 1. Unconfined compression value change of clayey soils with lime

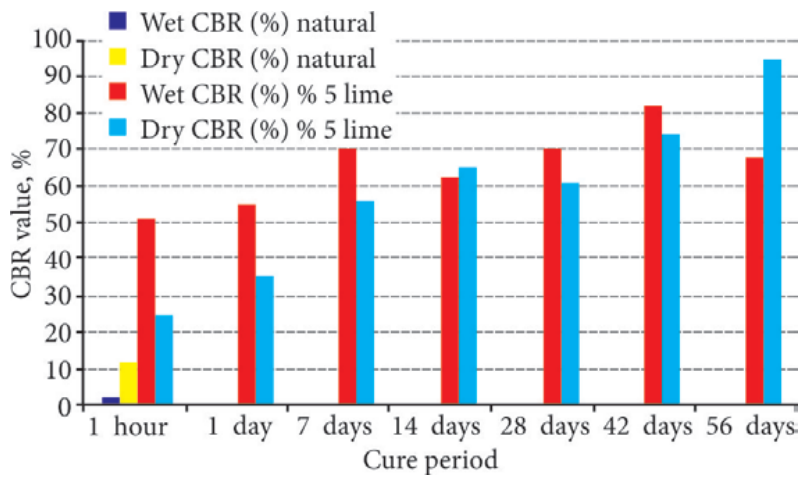

Figure 2. CBR experiment (Kavak et al., 2008)

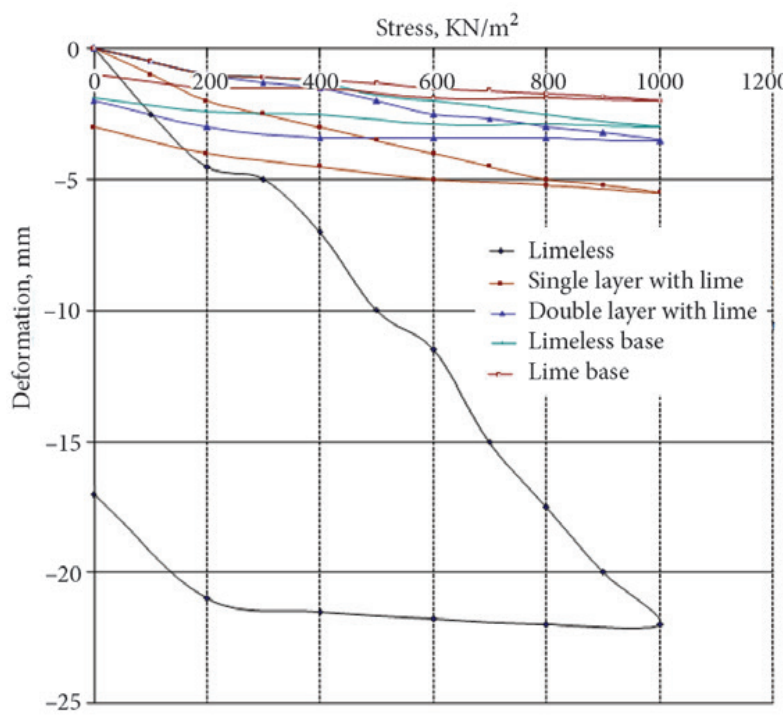

Figure 3. Graphical display of the plate loading experiments (Kavak et al., 2008)

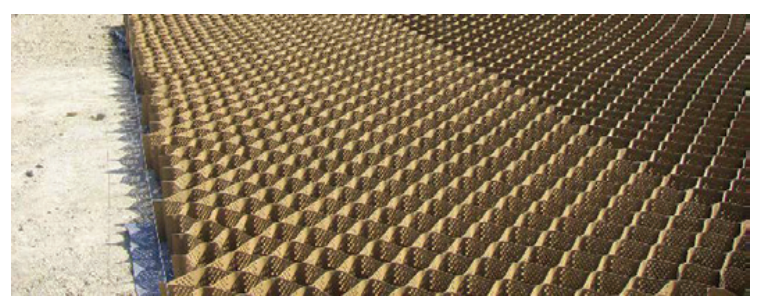

Figure 4. Application of cellular confinement system in the field (Ankara, Turkey)
As seen in Figure 4, cellular confinement system, filled with soil on the field, is a network having cells connected with nodes in the shape of a honeycomb made from polymer material. The cells take the vertical loading stresses at the vertical cell walls and soil resistance of the adjacent cells.

Moghaddas Tafreshi and Dawson (2010) using their laboratory model test reviewed comparison of bearing capacity of a strip base (plate) done on sand reinforced with geocell and strip base done on sand reinforced with a planar type geotextile. It was determined that geocell reinforcement significantly increases load-bearing capacity of the sand layer and decreases the settlements. It was concluded that an increase more than $200 \%$ of bearing capacity and a decrease up to $75 \%$ at the settlements may be achieved with geocell reinforcement.

Dash, Sireesh, and Sitharam (2003) reviewed the effect of geocell reinforcement placed in the granulated filling laid on soft clay with a small-scale model test in the laboratory. It was observed that an increase was achieved by geocell reinforcement on the bearing capacity and a significant decrease occurred at the surface swelling of the base. It was determined that an additional geogrid layer placed at the base of geocell would provide much more increased load-bearing capacity of the base. It was also concluded that seven times increase in bearing capacity may be achieved when geocell and geogrid reinforcement is used together.

Sireesh, Sitharam, and ve Dash (2009) reviewed the potential of sand reinforced with geocell on porous clay base by utilizing laboratory scale model test. Their study revealed the fact that 3-4 times improvement might be achieved on the performance with geogrid and geocell reinforcement in the granulated filling layer to be placed in the porous soft base. The study also resulted in a loadbearing capacity increasing up to approximately 40 times compared to porous soft clay layer.

Zhang, Zhao, Shi, and ve Zhao (2010) developed a simple performance model of geocells laid over soft base layer. The model and calculation procedures used in the study were proved with a laboratory experiment by tak- 
ing both distribution effect of geocell reinforcement on vertical stress. It was detected that geocell reinforcement placed in the crushed stone significantly increased bearing capacity of the soft base.

Latha and Somwanshi (2009) conducted model loading tests on geosynthetic reinforced sand. They reviewed performances of geocell and randomly distributed net meshed geogrid. The study suggested that bearing capacity was significantly affected by reinforcement type. It was concluded that geocell gave the highest bearing capacity potential among the reinforcement types.

In the study done by Dash, Krishnaswamy, and Rajagopal (2001a), the results of a strip plate supported by sand reinforced with a geocell were reviewed for laboratory model bearing test. The effect of various parameters such as the pattern of geocell formation, cell size, height and width of geocell, thickness of the material laid on the geocell, the resistance of geogrid used at the manufacture of geocell and relative density of the sand were reviewed at the test program. As a result of the study, it was observed that settlement behavior of strip plate placed on the sand reinforced with geocell was a linear event at a settlement up to $50 \%$ of approximate loading plate. Furthermore, the bearing capacity increased 8 times compared to the reinforced state. The study concluded the fact that the bearing strength used at the production of geocell is not an important parameter for assessing the performance of geocell but routing strips of geogrid and space size have an important effect on the load-bearing capacity of the base reinforced with geocell.

Zhou and Wen (2008) studied the development of bearing capacity of soft soil reinforced with the geosynthetic material. They stated that there was an important decrease of the soil settlement under the geocell laid over sand layer. The study showed that vertical deformation and surface stresses decreased $44 \%$ due to geosynthetic reinforcement (especially for geocell reinforced soil).

Zhang, Zhao, Zou, and ve Zhao (2009) reviewed a deformation controlled differential equity for geocell reinforcement under the vertical loads by taking internal surface resistance effect into consideration. Besides that, they reviewed appropriate power series, semi-analytic solutions and internal effects of geocell reinforcement for displacements. Also, the effect factors such as length and flexibility rigidity of the geocell reinforcement, internal surface resistance on stress-deformation characteristics and base reaction coefficient were discussed. At the end of the study, it was recommended to take internal surface resistance effect of geocell reinforcement on deformation into consideration in the engineering design.

Dash, Rajagopal, and Krishnaswamy (2001b) reviewed laboratory model test results on the strip plate. They concluded that a geogrid layer placed under the geocell generated much more increase in stability against rotation.

The use of geocells in pavement varies from one country to another due to varying on-site construction methods, calculations, and materials used in geocells. Vaitkus,
Šiukščius, and Ramūnas (2014) studied the relationship between regulations in Lithuania and other European countries. Calculation methods and regulations for controlling characteristics were introduced for the first time in Lithuanian. More research is needed to verify the calculations regulations often directly transferred from the standards to some developed countries.

Biabani, Ngo, and Indraratna (2016) studied the pullout strength of rail subballast reinforced with geocells. Mobilised tensile strength and passive strength of a subballast-geocell assembly under a vertical pressure ranging from $1 \mathrm{kPa}$ to $45 \mathrm{kPa}$ were measured. The laboratory large-scale pullout test results showed that the geocell reinforcement provides a significant passive resistance. The opening area and lateral pressure over the geocell strip were found to be important factors. Three-dimensional finite element simulation results showed that the tensile strength in the geocell will increase as the geocell stiffness increases.

Suku, Prabhu, Ramesh, and Babu (2016) studied the permanent deformation performance of geocell-reinforced base layer subjected to different repeated loading. The results showed that geocell decreases the vertical deformation of the unbound aggregate and reduces required thickness of the aggregate layer of unpaved roads.

Yang et al. (2012), utilized an accelerated pavement test on four unpaved road sections including geocell reinforcement of sand bases. Tensile and compressive stresses were measured beneath and outside the wheel path, respectively. Accelerated pavement test results showed that the geocell had a significant effect in reducing the rutting deformation of unpaved roads.

\section{Research methodology}

\subsection{Method}

In this paper, experimental studies were conducted on clay soil obtained from Trabzon Province in Turkey. Sieve analysis, consistency limit experiments and hydrometer analyses were applied on the soil material classified according to ASTM D3282-09. Modified proctor experiments were also conducted to determine optimum water content and dry unit weight of the clay material.

In this experimental study, plate loading tests were carried out on mixtures containing high clay and water content (20\% more moisture than optimum water content). Reaction modulus coefficient of clay soil, geocell reinforcement, lime $(5 \%, 10 \%, 15 \%)$ stabilization was compared to determine the effectiveness of these materials in pavement subgrades.

\subsection{Materials}

Lime $\mathrm{Ca}(\mathrm{OH})_{2}$ (calcium hydroxide) used in this study was "Barkisan" branded lime that was sold in the market in $25 \mathrm{~kg}$ packages and produced by TS 4022 . The chemical analysis of lime is given in Table 1 . 


\subsubsection{Cellular confinement system (Geocell)}

Texture (weave) type geocell manufactured from dense polyethylene $\left(0.95 \mathrm{gr} / \mathrm{cm}^{3}\right)$ was used in the plate loading experiment. Single cell diameter and height of the geocell was $25 \mathrm{~cm}$ and $20 \mathrm{~cm}$, respectively. Cells with $260 \mathrm{~cm}^{2}$ cross-sectional area were combined together to obtain a uniform geocell weld. It is worth mentioning that there

Table 1. Chemical analysis of lime, \%

\begin{tabular}{|c|c|}
\hline Chemical analysis & $\%$ \\
\hline $\mathrm{Ca}(\mathrm{OH})_{2}$ & $80-86$ \\
\hline Active $\mathrm{CaO}$ & $60.6-65.15$ \\
\hline Total $\mathrm{CaO}+\mathrm{MgO}$ & $85-95$ \\
\hline $\mathrm{MgO}$ & $1-3$ \\
\hline Density, gr/lt & $375-500$ \\
\hline
\end{tabular}

Table 2. Liquid limit and plastic limit experiments for natural soil and clay state

\begin{tabular}{|l|c|c|c|}
\hline \multicolumn{4}{|c|}{ Atterberg limits } \\
\hline & Liquid limit & Plastic limit & Plasticity index \\
\hline Natural & 58 & 25 & 33 \\
\hline $2.5 \%$ lime & 54 & 30 & 24 \\
\hline $5 \%$ lime & 53 & 33 & 20 \\
\hline $7.5 \%$ lime & 52 & 33 & 19 \\
\hline $10 \%$ lime & 52 & 38 & 14 \\
\hline $12.5 \%$ lime & 51 & 40 & 11 \\
\hline $15 \%$ lime & 51 & 42 & 9 \\
\hline
\end{tabular}

were $10 \mathrm{~mm}$ diameter drainage holes in the geocell walls. For dry sand, having $2 \mathrm{~mm}$ maximum grain diameters, the uniform curvature coefficient $\left(C_{u}\right)$, specific gravity, and voids rate were obtained as $3.06,1.05,2.63$, and 0.40 , respectively. Direct shear test results of sand resulted in an internal friction angle of $30^{\circ}$.

\subsubsection{Soil classification}

With the aim of classifying the material, Atterberg limits are given in Table 2. At the end of the classification the soil was determined as A-7 group clay soil according to ASTM D3282-09. Gradation curve of the three clay soils after wet sieve analysis showed practically identical gradation (curves overlaps). Dry sieving was unable to produce an acceptable degree of separation between the individual fractions. While test sieving on dry materials is recommended whenever possible, usually reproducible results are hard to obtain.

\subsection{Testing procedure}

Plate loading experiment was applied for stabilized soil containing lime at various rates and geocells. The plate loading experiment tool was $1 \mathrm{~m}^{3}$ cubic box as seen in Figure 5a with the aim of assessing the stress distribution and reaction coefficient values. The vertical load was applied with a hydraulic piston connected to a steel plate.

The sand was poured into the geocell loose until $5 \mathrm{~cm}$ thick layer was achieved on top of the geocell structure. The $5 \mathrm{~cm}$ sand layer was measured as $3 \mathrm{~cm}$ thick after compaction. The load was applied on top of the sand by the plate attached to the piston. The compaction process was carried out until the pressure gauge showed $40 \mathrm{kN} / \mathrm{m}^{2}$ value. b) placement of pressure and strain gauges, soil with high water content ( $45 \%$ ) prepared outside the test box
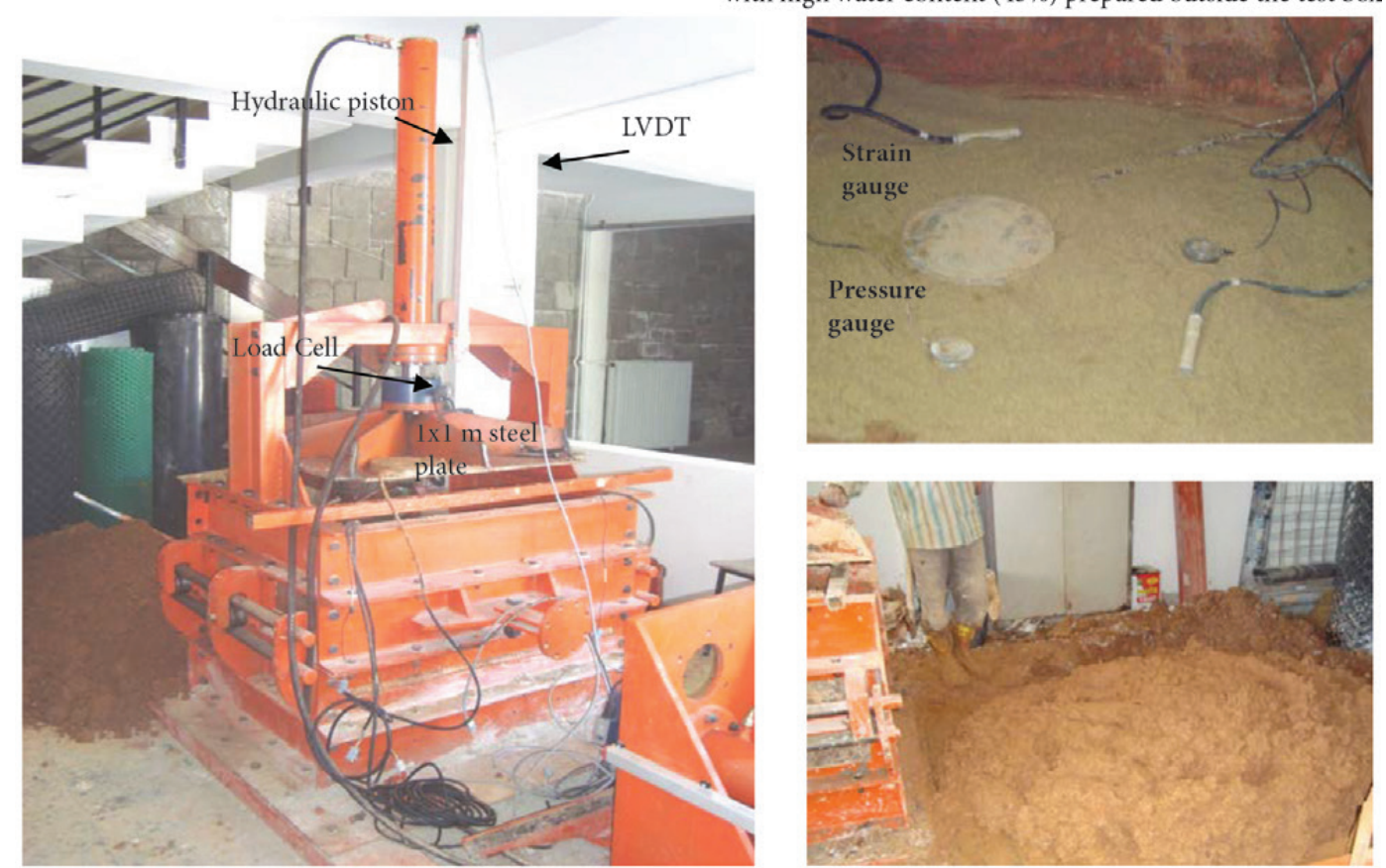

Figure 5. The plate loading experiment tool 
Field measurements showed that a typical 20.000 tons roller compactor has the capacity to apply $40 \mathrm{kN} / \mathrm{m}^{2}$ drum static linear load over subbase layer. Similarly, in this study, the piston load was applied over the sand layer and once the $40 \mathrm{kN} / \mathrm{m}^{2}$ stress was read by the data logger the compaction procedure was completed. In reality, this is also the case where the sand or gravel is dropped loose over the geocell and later compacted by the roller compactor. One disadvantage of this procedure was that it was almost impossible to measure the compaction uniformity of the geocell layer considering each cell. One way of getting good compaction on each cell is manual tamping which is not common in field application.

The clay soil with $45 \%$ water content prepared in the laboratory outside the experiment box was placed in the test box in $60 \mathrm{~cm}$ thick layers after compaction. Consolidation degree is a very important parameter when assessing the compression of clay. However, clay soil with high water content $(45 \%)$ was incompressible by nature. Once the pressure was applied on the natural high water content clay, the liquid clay leaked around and upwards the plate. Since mixing the sample with lime produced a quite stiff mixture, the very little movement was measured by the vertical displacement transducers (LVDT). The mixed samples were cured for 12 hours before testing which is the case on the field. When clays are present, the chemical reaction of limes with clays causes further drying. It would be possible to measure consolidation degree in case that the tests were performed immediately after mixing. In general, the upper pavement layers are constructed at least a few days later and the structure is open to traffic much later. During this time the lime mixed layer becomes even much stiffer.

Inside part of the test, the box was covered with the geomembrane to prevent friction between the fill material and test box surface. One $20 \mathrm{~cm}$ diameter gauge and two $5 \mathrm{~cm}$ diameter pressure gauges were used to measure the vertical stresses at the upper level and beneath the geocell (Zhang et al., 2009). Two strain gauges were used to measure the strain changes in the sub-base material. Stress and strain gauges are shown in Figure $5 b$.

Stress results from the lower gauges $(5 \mathrm{~cm}$ diameter) were used in the further analysis in Chapter 3. In this study, the piston load was applied over the sand layer and once the $40 \mathrm{kN} / \mathrm{m}^{2}$ stress was read by $20 \mathrm{~cm}$ diameter gauge located $5 \mathrm{~cm}$ beneath the load plate the compaction procedure was completed.

The geocell was filled with dry sand and then compressed (Figure 6). The surface of the geocell layer was covered with $3 \mathrm{~cm}$ thick sand layer. Nonwoven geotextile was placed over the soil material to separate the cellular confinement system. The soil with $45 \%$ high water content was stabilized with $5 \%, 10 \%$ and $15 \%$ lime

The plate loading experiments were done for natural soil (with $45 \%$ water content), natural soil + geocell, natural soil + lime at the rates of $5 \%, 10 \%, 15 \%$, natural soil + 5\% lime + geocell and natural soil $+10 \%$ lime + geocell. For all states, $30 \mathrm{~cm}$ diameter steel loading plate was placed on top of the compacted material that was placed in the test box. The loading continued until the vertical load reached to a single-axle load (single-axle load $=10$ tons, wheel load $=5$ tons).

\section{Results and discussion}

\subsection{Load-deformation}

Effects of lime stabilization and geocell reinforcement on clay soil with high water content were separately reviewed. The comparison of load-deformation relations of natural state, lime at the rates of $5 \%, 10 \%, 15 \%$, geocell, geocell $+5 \%$ lime and geocell $+15 \%$ lime are given at Figure 7 . When the results from Figure 7 are reviewed; while the largest deformation in the natural state of $10 \mathrm{~kg} / \mathrm{cm}^{2}$ stress was $61.32 \mathrm{~mm}$, this deformation was decreased to $53.80 \mathrm{~mm}, 39.21 \mathrm{~mm}$ and $28.92 \mathrm{~mm}$ when $5 \%, 10 \%$ and $15 \%$ lime was added, respectively. In case the base soil was reinforced with geocell, it was decreased to maximum $61.32 \mathrm{~mm}$ from $26.2 \mathrm{~mm}$ (in natural state), to 19.13 in $5 \%$ lime + geocell and $16.105 \mathrm{~mm}$ in geocell $+10 \%$ lime. Decrease of $10 \%, 35 \%, 40 \%$ in vertical deformation were observed with $5 \%, 10 \%, 15 \%$ lime stabilization, respectively.

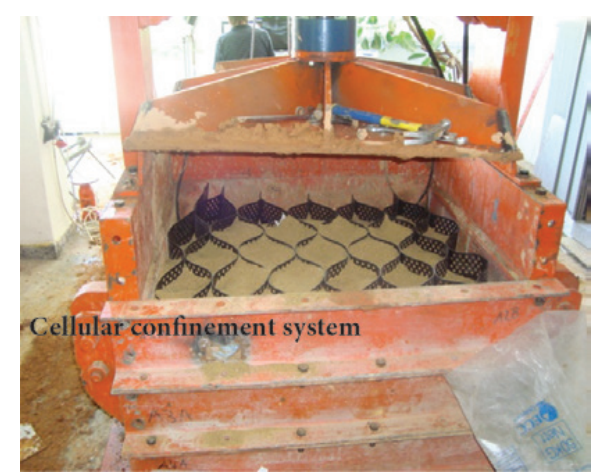

Figure 6. Confinement cells placed on the base soil were filled with sand

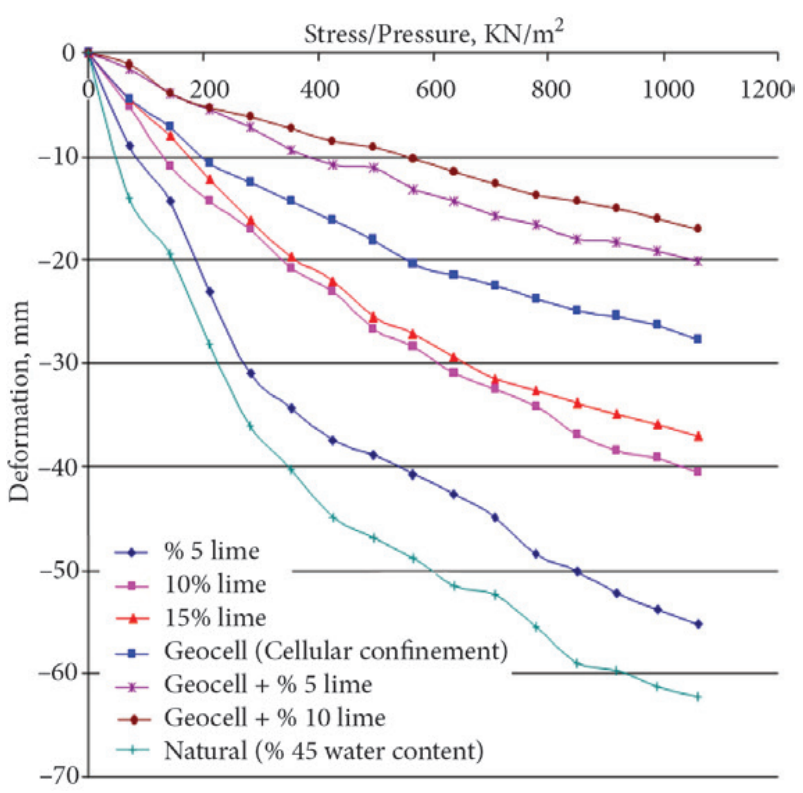

Figure 7. Load-deformation curve 
As seen, the amount of decrease at the deformation is little when lime is added to the soil after $10 \%$ lime rate. This is because of the decrease of CBR bearing capacity due to the increased amount of filler material. Better success, $55 \%$ and $75 \%$ decrease in deformation were achieved with geocell and geocell $+10 \%$ lime, respectively.

\subsection{Vertical stress}

The vertical stresses on unreinforced and geocell-reinforced base stabilized with lime at various percent are shown in Tables 3-4. The pressure gauges' readings, on either side of the piston, showed zero stress values at $40 \mathrm{~cm}$ distances. In case a comparison among lime stabilization and geocell reinforcement based on vertical stresses is made, the results have indicated that the vertical stresses on the base reinforced with geocell were only $10 \%$ less than the base stabilized with $15 \%$ lime. It has been seen that geocell reinforcement is more effective compared to lime stabilization in decreasing the vertical stresses due to the fact that the geocell material prevents the lateral movements of the fill material constrained inside due to its geometric structure. The vertical stresses at the bottom of the geocell were lowered by expanding the load to a wide area in the geocell structure. As a reaction, lateral stresses were also generated in congruent cells, which increased the shear strength of the confined soil. This creates a rigid mattress distributing the imposed pressure over a larger area thanks to the ability of geocells spreading imposed loads over a larger area.

The decrease of vertical stresses under the geocell shows similarity with the study done by Dash, Krishnaswamy and Rajagopal (2001a). In their study, they concluded that vertical stresses of the soil reinforced with geocell were decreased to the rates up to $50 \%$.

\subsection{Reaction modulus coefficient}

As a result of plate loading experiments, along with the coefficient values calculated with the help of load-deformation curves, the reaction modulus coefficient values were also obtained in case of using lime at various rates and geocell. These findings are represented in Figure 8. The review of reaction modulus coefficient values revealed that 2 times, 4 times and 5.5 times increases occurred in the state with $5 \%, 10 \%, 15 \%$ lime, respectively, compared to the state without lime. The reaction modulus coefficient value increased 6.5 times in the state of reinforcement with geocell compared to the unreinforced state. Furthermore, the 1.5-time

Table 3. Vertical stresses on unreinforced and geocell reinforced base

\begin{tabular}{|c|c|c|c|c|}
\hline \multirow{2}{*}{ Distance from the load, $\mathrm{cm}$} & \multicolumn{4}{|c|}{ Vertical stress, $\mathrm{kN} / \mathrm{m}^{2}$} \\
\cline { 2 - 5 } & Unreinforced & Soil+geocell & $5 \%$ lime+geocell & $10 \%$ lime+geocell \\
\hline 0 & 280 & 155 & 150 & 140 \\
\hline 20 (right) & 52 & 49 & 48 & 40 \\
\hline 40 (right) & 0 & 0 & 0 & 0 \\
\hline-20 (left) & 52 & 49 & 49 & 41 \\
\hline-40 (left) & 0 & 0 & 0 & 0 \\
\hline
\end{tabular}

Table 4. Base soil stabilized with lime

\begin{tabular}{|c|c|c|c|}
\hline \multirow{2}{*}{ Distance from the load, $\mathrm{cm}$} & \multicolumn{3}{|c|}{ Vertical stress, $\mathrm{kN} / \mathrm{m}^{2}$} \\
\cline { 2 - 4 } & $5 \%$ lime & $10 \%$ lime & $15 \%$ lime \\
\hline 0 & 265 & 220 & 470 \\
\hline 20 (right) & 135 & 49 & 0 \\
\hline 40 (right) & 0 & 0 & 46 \\
\hline-20 (left) & 134 & 48 & 0 \\
\hline-40 (left) & 0 & 0 & 46 \\
\hline
\end{tabular}
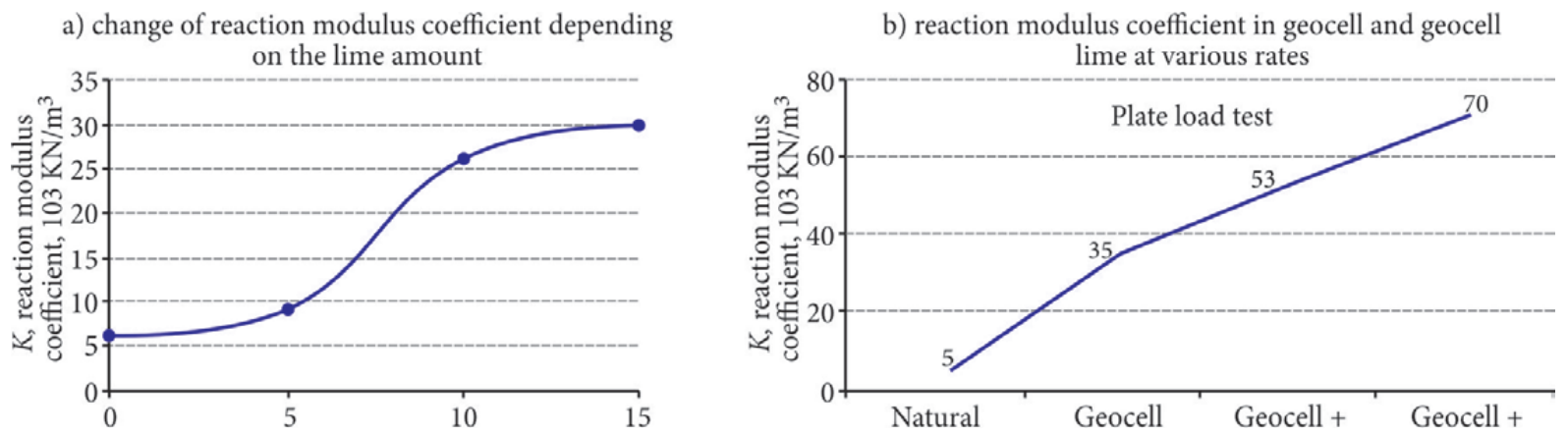

Figure 8. Reaction modulus coefficient values in case of using lime at various rates and geocell 
increase is the obtained result compared to the $10 \%$ lime stabilized state. In the case of $10 \%$ lime-stabilized geocell state reinforced base soil, the reaction modulus coefficient value increases about 14 and 2.5 times compared to the natural state and the base soil stabilized with $15 \%$ lime, respectively.

The reaction modulus coefficient value continuously increases up to $10 \%$ lime rate in case a soil with high water content is stabilized with the lime. After 10\% lime rate, however, the increase rate becomes lower. According to Turkish highways technical specification, Ulaştırma (2013), the pavement base soil reaction modulus coefficient $(K)$ shall be higher than $5.5 \mathrm{~kg} / \mathrm{cm}^{2}$. Pursuant to this standard, these values were hardly reached. But for when the clay base of high water content is stabilized with $10 \%$ lime and then reinforced with the cellular load-bearing system, the $K$ value of $6.5 \mathrm{~kg} / \mathrm{cm}^{2}$ was reached satisfying highway need.

\section{Conclusions and recommendations}

In this paper, the effects of stabilization of paved road base soil having high water content and clay with lime or reinforcement of cellular system and together the use of these two different improvement methods were reviewed. The following conclusions are made through the findings of the experiments conducted.

1. As a result of the plate loading experiments, it was observed that lime stabilization and cellular confinement system increase the reaction modulus. On the other hand, a decrease in the vertical stress and vertical deformation was obtained compared to the natural state (with a high water content of $45 \%$ ).

2. It was determined that cellular reinforcement increased the value of reaction modulus coefficient for the base soil more than $15 \%$ compared to the lime stabilization and decreased the settlements along with vertical stresses by $13 \%$.

3. Finally, it was concluded from this experimental study that sole lime stabilization or improvement with cellular bearing systems more or less fulfil the required reaction modulus coefficient values recommended by the state engineers for A-7 group clay paved base soils with high water content. As the solution to this problem, though, it is recommended that stabilization of these types of soils need to be implemented through the successive lime stabilization and cellular confinement systems.

\section{References}

ASTM D3282-09. Standard Practice for Classification of Soils and Soil-Aggregate Mixtures for Highway Construction Purposes. American Society for Testing and Materials. Retrieved from https://www.astm.org/mobile.old/standards/D3282.htm

Biabani, M. M., Ngo, N. T., \& Indraratna, B. (2016). Performance evaluation of railway subballast stabilized with geocell based on pull-out testing. Geotextiles and Geomembranes, 44(4), 579-591. https://doi.org/10.1016/j.geotexmem.2016.03.006

Dash, S. K., Krishnaswamy N. R., \& Rajagopal, K. (2001a). Bearing capacity of strip footings supported on geocell-reinforced sand. Geotextiles and Geomembranes, 19(4), 235-256. https://doi.org/10.1016/S0266-1144(01)00006-1

Dash, S. K., Rajagopal, K., \& Krishnaswamy, N. R. (2001b). Strip footing on geocell reinforced sand beds with additional planar reinforcement. Geotextiles and Geomembranes, 19(8), 529-538. https://doi.org/10.1016/S0266-1144(01)00022-X

Dash, S. K., Sireesh, S., ve Sitharam, T. G. (2003). Model studies on circular footing supported on geocell reinforced sand underlain by soft clay. Geotextiles and Geomembranes, 21, 197-219. https://doi.org/10.1016/S0266-1144(03)00017-7

Kavak, A. (1996). The behavior of lime stabilized clays under cyclic loading (PhD Thesis). Boğaziçi Üniversitesi, Fen Bilimler Enstitüsü, İstanbul, Turkey.

Kavak, A., Güngör, A. G., Avşar, C., Atbaş, B., \& Akyarlı, A. (2008). A lime stabilization application on a divided road project. Zemin Mekaniği ve Temel Mühendisliği Onikinci Ulusal Kongresi (pp. 16-17). Selçuk University, Konya.

Latha, G. M., \& Somwanshi, A. (2009). Effect of reinforcement form on the bearing capacity of square footings on sand, International Journal of Engineering Science, 27, 409-422.

Moghaddas Tafreshi, S. N., \& Dawson, A. R. (2010). Comparison of bearing capacity of a strip, footing on sand with geocell and with planar forms of geotextile reinforcement. Geotextiles and Geomembranes, 28, 72-84.

https://doi.org/10.1016/j.geotexmem.2009.09.003

Sireesh, S., Sitharam, T. G., ve Dash, S. K. (2009). Bearing capacity of circular footing on geocell - sand mattress overlying clay bed with void. Geotextiles and Geomembranes, 27(2), 89-98. https://doi.org/10.1016/j.geotexmem.2008.09.005

Sivapullaiah, P.V., Kantha, H. L., \& ve Kıran, K. M. (2003). Geotechnical properties of stabilised indian red earth. Geotechnical and Geological Engineering, 21, 399-413. https://doi.org/10.1023/B:GEGE.0000006051.02215.a6

Suku, L., Prabhu, S. S., Ramesh, P., \& Babu, G. L. S. (2016). Behavior of geocell-reinforced granular base under repeated loading. Transportation Geotechnics, 9, 17-30. https://doi.org/10.1016/j.trgeo.2016.06.002

Ulaştırma, T. C. (2013). Denizcilik ve Haberleşme Bakanlı̆ı Karayolları Genel Müdürlüğü. Karayolları Teknik Şartname, Ankara.

Vaitkus, A., Šiukščius, A., \& Ramūnas, V. (2014). Regulations for use of geosynthetics for road embankments and subgrades. The Baltic Journal of Road and Bridge Engineering, 9(2), 8893. https://doi.org/10.3846/bjrbe.2014.11

Yang, X., Han, J., Pokharel, S. K., Manandhar, Ch., Parsons, R. L., Leshchinsky, D., \& Halahmi, I. (2012). Accelerated pavement testing of unpaved roads with geocell-reinforced sand bases. Geotextiles and Geomembranes, 32, 95-103. https://doi.org/10.1016/j.geotexmem.2011.10.004

Yıldırım, B., Alataş, T., \& Dağdelen, Ş. (2009). Zemin Stabilizasyonunda Bitüm Kullanılması ile Üst Yapıda Sağlanacak konominin Araştırılması. İMO, 4, 13-17.

Zhang, L., Zhao, M., Zou, X., \& ve Zhao, H. (2009). Deformation analysis of geocell reinforcement using Winkler model. Computers and Geotechnics, 36, 977-983. https://doi.org/10.1016/j.compgeo.2009.03.005

Zhang, L., Zhao, M., Shi, C., ve Zhao, H. (2010). Bearing capacity of geocell reinforcement in embankment engineering. Geotextiles and Geomembranes, 28, 475-482.

https://doi.org/10.1016/j.geotexmem.2009.12.011

Zhou, H., \& Wen, X. (2008). Model studies on Geogrid - or Geocell - reinforced sand cushion on soft soil. Geotextiles and Geomembranes, 26, 231-238.

https://doi.org/10.1016/j.geotexmem.2007.10.002 